\title{
The importance of the generation and size category factors in the financing decision of family-owned firms
}

\section{La importancia de los factores de generación y categoría dimensional en la decision de financiación de las empresas familiares}

\author{
Rui Manuel Sobral Rita
}

Escola Superior de Ciências Empresariais do Instituto Politécnico de Setúbal, Setúbal (Portugal)

\section{A T OS A R T Í C U O}

\section{Historial:}

Recibido 09-02-2013

Aceptado 27-05-2013

Palabras clave:

Propiedad de la familia

Generación

Dimensión

Deuda

Códigos JEL:

C31,C58,D82,G32

\section{RES UMEN}

Las empresas familiares tienen niveles de deuda más altos en comparación con las empresas no familiares. Este hecho corrobora la corriente de la literatura financiera de defensa de este comportamiento. El vencimiento de la deuda influye en este resultado. Las empresas familiares tienen niveles más bajos de deuda a largo plazo. En el ámbito de las fuentes, las empresas familiares más pequeñas tienen una mayor utilización de fundo de los socios y de la deuda de proveedores de bienes de equipos, en particular, las empresas de primera generación. Las segundas generaciones tienen niveles de deuda más bajos. Las empresas familiares más grandes tienen una menor frecuencia de deuda nula a largo plazo comparativamente a las empresas no familiares y una relación negativa entre el tamaño y la deuda nula, pero en el caso de las microempresas, este hecho es al revés. Los valores nulos de la deuda son pertinentes. Estos resultados se mantienen en la situación específica de la deuda bancaria. Modelos revelan algunas diferencias entre los determinantes de la utilización de la deuda en comparación con los que determinan su proporción.

\footnotetext{
A B S T R A C T

Family firms have higher levels of debt than non-family firms corroborating the financial theory forecasting this behavior. The maturity of debt affects this result. In long-term debt family firms show lower levels than non-family firms. As for financing sources, smaller family firms make more use of owners' funds and equipment suppliers' credit to finance their needs, particularly first-generation firms. The second generation has a lower level of debt than the first. Larger family firms have a lower frequency of zero long-term ratios than their non-family counterparts and a negative relationship between size and zero debt ratio, but in the case of micro firms, this is reversed. Zero debt ratios are relevant in the sample. These results hold true in the specific situation of bank debt. The models revealed some differences between the determinants of the use of debt and those determining its proportion.
} 


\section{Introduction}

Family firms are of great importance in the global economy due to their influence in the creation of employment and wealth in a considerable number of countries (Schulz et al, 2001). In many, they account for around two thirds of private economic entities. In Western Europe, family firms represent between 75\% and $95 \%$ of registered firms (Lank, 1995). The majority of new firms created are family-owned (Westhead and Howorth, 2007). Their survival and development has a great impact on the progress of local economies and social cohesion. According to Neubauer and Lank (1998), these firms have the greatest impact on economic growth, as producers, employers and innovators.

Assessment of business structure reveals the relevant role of family firms in the economies of most countries. However, the financial literature shows a gap regarding theoretical and empirical contributions that clarify how the familyownership factor and its specificities determine the decision process, and specifically that of financing. Nevertheless, ownership and/or firm control has been mentioned in the literature as a determinant of the financing decision process (La Porta et al, 1999; Friend and Lang, 1988; Brailsford et al, 2002). Particularly, study of the decision process of family firms has emerged as a subject of research but there is still a great need to clarify how this decision is made in this type of firm (López-Gracia and SánchezAndújar, 2007; Blanco-Mazagatos et al, 2007; Gallo et al, 2004).

In the business world, family firms have a variety of unique characteristics that distinguish them from others. Among them stands out the relationship between the family and operations, specifically the overlapping roles of being a family member and an element of firm management. Personalization of the family business is carried over to business relationships (with clients, suppliers, creditors and others) (Harvey and Evans, 1995). The overlapping of family and business activity can create particular attitudes in relation to financing strategy (López-Gracia and Sánchez-Andújar, 2007).
Alcorn (1982) identifies three stages in family firms: the undertaking, maturity and succession. In the first, efforts are directed to building a solid economic base for the firm. Managing growth and ensuring financial viability are critical tasks. In this phase, the owner is more inclined to take risks. The need for security, in personal and business life, occurs in the period of maturity. This phase requires greater competences by the owner in managing the interests of the different stakeholders. Finally, in the third stage, the concern about succession emerges. Ward (1988, 1991) also presents a three-stage model of family firm development, based on age and the characteristics of two generations of family members: initial (0-5 years), intermediate (1020 years) and final (20-30 years).

Handing over or transferring the business to the next generations is a determinant of the financing decision, and possibly a differentiating one in the process. Sonfield and Lussier (2004), in their study of the choice of financing sources, found that $61 \%$ of firstgeneration firms resorted more to financing through equity rather than debt. In secondgeneration firms, the figure only reaches $11 \%$, being $33 \%$ in the third generation. These results indicate use of lower levels of debt by the first generation than the following ones. Of these, the second generation greatly increases the firm's level of debt. The third generation adopts a more modest level of debt than the second. Greater use of equity by first-generation firms (less debt) was also found by Bork et al (1996) and Gersick et al (1996). In the case of thirdgeneration firms compared to second-generation ones, Cole and Wolken (1995) and Coleman and Carsky (1999) corroborate this behaviour. According to the study by Dyer (2003), around $4 / 5$ of first-generation firms have a 'fatherfigure' management style and culture ${ }^{1}$ and in the following generations, $2 / 3$ are found to adopt a more professional style of management. Ward

\footnotetext{
${ }^{1}$ According to the author, 'father-figure' management is characterized by a hierarchy of relationships, control and authority from top management downwards, close supervision and mistrust of outside bodies. Professional management involves the inclusion, and sometimes predominance, of non-family managers in the firm.
} 
(1987), quoted by Romano et al (2000), highlights the fact that family firms typically reinvest most, or even all, their funds in the initial stages of their life-cycle. In the following stages, owners tend to use more firms' results as a consequence of the family's growing desire for better financial well-being. The matter of succession in firm management is also relevant in distinguishing family and non-family firms. In the latter, that succession is analyzed and assessed in advance. In the former, precisely the opposite may occur (Dreux, 1990). Coleman and Carsky (1999), quoting De Visscher et al (1995), highlight the fact of financing being one of the main challenges for family firms and the major cause of their failure is insufficient capital and liquidity. Tranferring ownership can exacerbate this problem as the following generations may have different business and financial objectives from the founders. Around $2 / 3$ of first-generation family firms do not survive the second generation (Gersick et al, 1996).

The influence of the size factor on firms' financing decision process is not clarified. The majority of previous empirical studies focus on SMEs as a uniform group, ignoring the fact that different factors can affect the financing decision of different sizes in considerably different ways (Ramalho and Silva, 2009). In those studies, it is also common to compare that group with large or small firms (Ebben and Johnson, 2006; Cassar and Holmes, 2003; Hall et al, 2000; López-Gracia and Aybar-Arias, 2000; Chittenden et al, 1996, among others). In this respect, there is a lack of research into the financing process distinguishing different size categories, particularly among smaller firms. That lack is especially evident in the study of the financing decision of micro and small firms separately, except for the studies by Ramalho and Silva (2009), Akyüz et al (2006), Cassar and Holmes (2003) and López-Gracia and Aybar-Arias (2000).

Besides evaluating the factors of ownership, generation and size, greater clarification of firms' financing decision process will be reached taking into consideration that this is developed in two distinct stages. The first, in which firm leaders decide whether or not to use debt, and the second, if the decision is to use it, determining the proportion. This approach to studying the financing decision considering the two moments or phases of the decision is the result of the recent conclusions presented by Cassar (2004), Faulkender and Petersen (2006), Kurshev and Strebulaev (2006), Strebulaev and Yang (2006) and Ramalho and Silva (2009) on the existence of a relevant number of firms without, or with low amounts of financial debt, indicating firms' option not to resort to this source of finance. "...firms have the opportunity to increase their leverage and are choosing to leave money on the table." (Faulkender and Petersen, 2006:46).

\section{Determinants of the Financing Decision in the Financial Literature}

\subsection{Capital Structure Theories}

According to the financial literature, it was the work of Modigliani and Miller (1958) (MM) that gave rise to a vast amount of theoretical and empirical literature on the subject of the determinants of firms' capital structure. These authors opposed the classical theory defending the existence of an optimal capital structure that maximizes firm value through reducing the average cost considered of firms' capital. MM introduced the irrelevance of firms' capital structure $^{2}$ for their value. This depends only on the level and risk of future cash flow created by real assets, making the financing decision irrelevant.

Static trade-off theory once again introduces the existence of an optimal capital structure that allows maximization of the firm's value through the benefits and costs associated with each source of finance (such as bankruptcy costs, costs associated with obtaining from each source, tax benefits and others).

The appearance of the fiscal line of thought came to highlight the differences in taxation

\footnotetext{
${ }^{2}$ On the assumption of the perfect capital market, non-existence of tax and transaction costs.
} 
attributed to the various sources of finance. This factor led MM (1963) to change their original position, stating that taxation of firms' results and tax deduction on the cost of outside capital could allow firms' value to increase. Miller (1977) concludes that the existence of different agents with differentiated rates of tax leads to firms issuing different bonds in the financing decision. DeAngelo and Masulis (1980) introduced the fact of other sources of tax benefits being able to reduce the appeal of external capital as a function of these benefits.

Another theory introduces the matter of agency relationships and the financing decision. According to Agency Theory, the interests of the principal and the agent do not coincide and in the absence of a suitable incentive and monitoring system, the agent will act in order to maximize his utility (Jensen and Meckling, 1976). In business finance, this theory has been applied to studying the relationships between firm managers and shareholders/owners. Therefore, in this approach, it is argued that while firm owners aim to maximize profit, their agents (managers) may prefer to undertake activities in their own interests which do not maximize profit. In this way, firm performance depends to some extent on owners' efficiency in controlling and monitoring their agents (Gedajlovic and Shapiro, 1998). The costs of these control and monitoring activities are agency costs (Smith, 2008). Jensen and Meckling (1976) argue the conflicts that may exist between shareholders, managers and creditors and the problem of asset substitution originate agency costs and influence determination of firms' capital structure. The same authors say that financing through external capital can discipline managers' behaviour. Derived from agency costs, Myers (1977) points out that the type of assets can determine the type of finance.

The importance of the bankruptcy issue, the respective costs for firms and their influence on their governance led to introduction of the bankruptcy costs approach, as proposed by Kraus and Lintzenberger (1973). For the authors, the value of an indebted firm would be equal to a firm with no debt plus the value of the debt, less bankruptcy costs. More debt increases the firm's exposure to possible difficulties in meeting its commitments, i.e., increasing the expected bankruptcy costs.

The theory based on information asymmetry is formed of two lines of thought: pecking order and signaling. The former defends that firms do not have an optimal debt ratio and the financing decision is based on the problem of information between the firm's external and internal agents. Therefore, those in charge of firms prefer to finance themselves firstly through self-financing and if these funds are not sufficient, they then turn to risk-free debt, followed by risky debt and finally issuing equity (Myers and Majluf, 1984). the latter approach was stimulated by Ross (1977) and Leland and Pyle (1977). The first author argues that investors interpret high levels of debt as a sign of the firm's high quality and that profitability and debt are positively related. The others, on the contrary, argue that a business-person with a new investment project can indicate its quality through the proportion of equity used to finance it. The value will increase with the increase in the owners' shares.

Another approach introduced is the theory based on corporate control. "Following the growing importance of takeover activities in the 1980s, the finance literature began to examine the linkage between the market for corporate control and capital structure." (Harris and Raviv, 1991:319). La Porta et al (1999) refer to the excessive control of cash flow rights arising from the strong presence of the owners in firm management. Their characteristics (families, financing bodies) determine the financing decision. The concentration or dispersion of ownership is a determinant of the financing decision (La Porta et al, 1999 and Rajan and Zingales, 1995). Firms that are an attractive target for acquisition offers will tend to increase their levels of debt (Rajan and Zingales, 1995; Harris and Raviv, 1988).

\section{Methodologies and Hypotheses}

\subsection{Methodologies}


This study resorts to the two-part fractional regression model so as to test and identify, separately, the determinants of the use and proportion of debt. An aspect emerging from empirical studies about the financial decision, and relevant for the decision on the functional form to apply, is separating analysis of the factors determining the decision to use debt from the factors determining its proportion (Cassar, 2004; Faulkender and Petersen, 2006; Kurshev and Strebulaev, 2006; Strebulaev and Yang, 2006). In this connection, the Two-Part Fractional Regression Model presented by Ramalho and Silva (2007) emerges. According to the authors, this model plays an important part in studying firms' financing decision because it includes the advantages of the fractional regression model (according to Ramalho and Silva, this econometric model is appropriate for the characteristics of the subject of study explaining the behaviour of a dependent variable with values between 0 and 1), adding the possibility of this functional form allowing separate analysis of the factors determining the decision on debt compared to those determining its proportion. This is specified in two parts: the first is a binary model explaining the probability of the firm deciding whether to use debt or not:

$$
\begin{gathered}
Y^{*}=\left\{\begin{array}{l}
0 \text { if } Y=0 \\
1 \text { if } Y \in[01]
\end{array}\right\} \\
\operatorname{Pr}\left(Y^{*}=1 \mid X\right)=\operatorname{Pr}(Y \in[01] \mid X)=F(X \theta)(2)
\end{gathered}
$$

Where $\theta$ corresponds to the vector of the coefficients of the explanatory variables and $F($.) is the function of the logistic or normal distribution. Resulting from this form, in the Logit and Probit model, respectively, they can be estimated through the maximum likelihood method. The second part of the model considers study of the determinants of the amount of debt to be issued by firms with debt ratios above zero. In this study, we chose to apply the fractional regression model previously referred to, applied only to the sample of firms presenting a positive debt ratio.

$$
E(Y \mid X, Y \in[01]=G(X \gamma)
$$

\subsection{Hypotheses}

Four hypotheses are identified directly related to the central aims of this research work:

Hypothesis 1: "Family Firms present a different financial structure from their nonfamily counterparts due to a process decision determined by different factors." - The decision process of both family and non-family firms involves a set of common and different aspects and factors, as seen in the previous chapters. And given the matter of the attitude towards financial risk, ownership and other aspects, a different financial structure is expected between family and non-family firms.

Hypothesis 2: "Family firms of the second and subsequent generations present a different financial structure from that of first generation firms." - The financial literature attributes great importance to the matter of the generation in the way firms develop their decision process and governance, particularly in the case of family firms. The second and subsequent generations tend to adopt a different attitude from the first regarding matters such as risk, ownership and management.

Hypothesis 3: "The size factor has a fundamental role in the financing decision process, differentiating the financial structure of micro, small and medium-sized/large firms". The size factor has been widely referred to in the financial literature as a determinant of the financing decision. Firms of different sizes present different problems of information asymmetry, agency problems and others which determine their access to certain sources of finance. It is therefore important to analyze how this factor behaves in distinguishing between family and non-family firms and the respective decision process.

Hypothesis 4: "Family firms present differences between the factors determining the use of debt and those determining its proportion. There are also differences in these factors between family and non-family firms." The work by Ramalho and Silva (2009) and Cassar (2004), concerning clarification of the 
determinants of firms' capital structure, mentions the need to develop study of the financing decision in two phases or moments. The first phase consists of the decision to use, or not to use, a given source. After choosing that source, it is necessary to decide on the amount or proportion. The former authors state that the determinants of the financing decision at the first stage will not necessarily be the same as those determining the second stage, and therefore do not imply action in the same direction. It is therefore important to analyze this aspect in family and non-family firms.

\section{Table 1}

Determinants of capital structure.

\begin{tabular}{ll} 
Factor & Measure \\
\hline Age & $\begin{array}{l}\text { Number of Years } \\
\text { between the firm's } \\
\text { foundation and the } \\
\text { sample period }\end{array}$
\end{tabular}

\section{Relationship with Debt}

A significant relationship between firm age and level of debt - this variable has been used as a determinant of the capital structure decision and can represent two opposing sign effects. If the variable is used to represent the firm's reputation, a positive sign is expected with debt. A more mature firm, presenting greater fame and recognition by the financial market, has easier access. This maturity can also mean a past of accumulating internally generated funds (through a history of positive results) and in this case, a negative relationship with debt is expected, due to greater accumulation of funding meaning less need for debt. In the case of family firms, the doubt concerning the duality of the sign of the relationship is strengthened, given the various arguments pointed out in the financial literature on debt in these firms. The approach defending less debt in family firms justifies that hypothesis with their leaders' aversion to financial risk, mainly in founders or the first generation. But that aversion tends to diminish in subsequent generationsas.

\begin{tabular}{lll}
\hline Size & Natural Logarithm & A positive relationship with debt - Access to the financial and capital market is fundamental in firms' financing
\end{tabular} of Turnover decision process, meaning a greater number of possible sources of finance. The size factor and access to the market are closely related. Larger firms have easier access due to fewer problems of information asymmetry, moral and financial hazard, as explained in the previous sections.

Profitabil Ratio of EBIT to A negative relationship with debt - Firm leaders' preference for the use of internally generated funds in the ity Total Assets financing decision is widespread in the financial literature. The theory of pecking order of financing sources assumes internal funds to be the first preference. In family firms, this preference is extremely relevant given firm owners' aversion to financial risk and opening up capital. A negative relationship is therefore expected, since greater profitability implies greater capacity to generate internal funds and less need to resort to external funding.

\begin{tabular}{|c|c|c|}
\hline $\begin{array}{l}\text { Tangible } \\
\text { Assets }\end{array}$ & $\begin{array}{l}\text { Ratio of } \\
\text { Assets to } \\
\text { Assets }\end{array}$ & $\begin{array}{l}\text { positive relationship with debt - In financing through external funding, a firm's capacity to present assets with } \\
\text { llateral value, which can be used as a guarantee in the case of failing to meet commitments related to those } \\
\text { ternal funds, is a relevant aspect in easing access to the financial market. Therefore, a greater volume of tangible } \\
\text { sets, and therefore more collateral value, is expected to mean a positive relationship with debt }\end{array}$ \\
\hline $\begin{array}{l}\text { Average } \\
\text { Tax Rate }\end{array}$ & $\begin{array}{l}\text { tio of } \operatorname{Tax} \text { on } \\
\text { ome to Results } \\
\text { fore Tax }\end{array}$ & $\begin{array}{l}\text { positive relationship with debt - Haugen and Senbet (1988) state that a positive relationship is expected } \\
\text { etween the tax rate on income and debt, because the interest that can be deducted, for firms with a high rate of tax, } \\
\text { lakes it an incentive to using more debt. The costs of finance through outside capital can be deducted in } \\
\text { etermining the amount to be taxed, implying more tax benefits through this source of finance. Increased tax rates } \\
\text { ad to increasing the value of those benefits. }\end{array}$ \\
\hline$R \& D$ & $\begin{array}{l}\text { tio of } R \& D \text { to } \\
\text { tal Net Assets }\end{array}$ & $\begin{array}{l}\text { negative relationship with debt - Balakrishnan and Fox (1993) highlight the specific nature of assets as a source } \\
\text { problems in terms of financing, due to the characteristics of not reusing these assets. The agency costs associated } \\
\text { th intangible assets are higher than with tangibles (Myers, 1977). }\end{array}$ \\
\hline $\begin{array}{l}\text { No Debt } \\
\text { Taxes } \\
\text { Shields } \\
\text { (NDTS) }\end{array}$ & $\begin{array}{l}\text { Ratio of } \\
\text { Amortization and } \\
\text { Provisions to } \\
\text { Total Net Assets }\end{array}$ & $\begin{array}{l}\text { A negtive relationship with debt - According to the arguments of Titman and Wessels (1988), the tax reduction } \\
\text { on amortization and tax credits for investment are substitutes for the tax benefits obtained through financing with } \\
\text { external capital. Consequently, it is expected that firms with high tax benefits unrelated to debt in relation to their } \\
\text { cash flow expectations, will include less debt in their capital structure. }\end{array}$ \\
\hline Liquidity & $\begin{array}{l}\text { Ratio of } \\
\text { Avaliabilities to } \\
\text { Total Net Assets. }\end{array}$ & $\begin{array}{l}\text { negative relationship with debt. - According to Antoniou et al (2006), firms with sufficient liquid assets do not } \\
\text { ed to increase debt, and low debt can consequently be expected. This situation is related to the theory of pecking } \\
\text { ler, according to which managers prefer self-financing. Therefore, they will seek to create reserves from the } \\
\text { ults obtained to finance future investment. Manos et al (2001) present a positive relationship between this } \\
\text { riable and level of debt because demonstration of firms' ability to meet their commitments increases their } \\
\text { aacity for debt. }\end{array}$ \\
\hline Gro & $\begin{array}{l}\text { Annual Growth } \\
\text { Rate of Assets } \\
{[(\text { Assets year } \mathrm{n}-} \\
\text { Assets year } \mathrm{n}-1) \text { / } \\
\text { Assets year } \mathrm{n}-1] \text { - } \\
1\end{array}$ & $\begin{array}{l}\text { A positive relationship with debt - Firm growth is associated with grea } \\
\text { development. Thies and Klock (1992) identified a positive relationship betwe } \\
\text { stage of growth do not have sufficient internal funds to finance it, and seek d } \\
\text { of equity. Firm growth, among other things, is the consequence of increa }\end{array}$ \\
\hline $\begin{array}{l}\text { Working } \\
\text { Capital } \\
\text { Needs }\end{array}$ & $\begin{array}{l}\text { Need for Working } \\
\text { Capital }=[(\text { Stocks } \\
+\quad \text { Clients } \quad- \\
\text { (Suppliers } \quad+ \\
\text { State)]/Assets. }\end{array}$ & $\begin{array}{l}\text { ositive relationship with debt - Together with investment in tangible assets, financing working capital needs is } \\
\text { of the concerns related to the financing decision. The financial literature states that keeping a balanced financial } \\
\text { icture involves financing the needs of extra permanent exploration considering the permanent exploration } \\
\text { purces available with permanent capital. Therefore, firms with higher levels of these needs are expected to } \\
\text { sent higher levels of debt. }\end{array}$ \\
\hline Industry & $\begin{array}{l}\text { Agriculture, } \\
\text { Industry, } \\
\text { Construction, } \\
\text { Commerce, } \\
\text { Accommodation }\end{array}$ & $\begin{array}{l}\text { an and Wessels (1988) establish a relationship between industry type and debt, with a negative relationship } \\
\text { veen the degree of firm specialization and its level of debt. The category of industry is a potential determinant of } \\
\text { tal structure because firms in the same industry face similar market conditions and have similar risk } \\
\text { acteristics (Brailsford, 1999). The specific nature of the activity carried out influences debt by determining } \\
\text { ous factors related to firms. }\end{array}$ \\
\hline
\end{tabular}


According to the contributions of capital structure theories relating to the determinants of capital structure, the control variables are included in table 1.

\section{Sample and Descriptive Analysis}

\subsection{Sample}

Classification of family and non-family firms in this study, as in the work by López-Gracia and Sánchez-Andújar (2007) Blanco-Mazagatos et al (2007) and Ménendez-Requejo (2006), is guided by the information supplied by the database used - SABI - Analysis System of Iberian Balance Sheets, managed by the firms of Coface, Informa and BvD. This does not guarantee complete information about family members' participation in firm management. Despite this limitation, the informative capacity of this database is recognized, and it was decided to follow the methodology adopted by these authors in selecting the sample classified as family firms. Firms where individuals or the family hold $51 \%$ or more of capital were classified as family firms. the samples representing family and non-family firms will be divided in three groups according to size: micro, small, medium-sized/large. The methodology used to classify firms in the three size categories was that presented in the European Commission Recommendation of 6 May 2003 ( $\left.n^{\circ} 2003 / 361 / C E\right)$. The main criterion was therefore the number of employees, complemented by a financial criterion (total assets or turnover), as mentioned in Point 4 and Article 2 of the respective attachment of the recommendation.

\subsection{Descriptive Analysis}

The financial literature recognizes the importance of the generation factor in firms' governance. Handing over the firm to the next generation produces effects on the financing decision. Specifically referred to is less aversion to debt and to opening up capital in the second and subsequent generations. Table 1 reveals less debt in firms of the second and subsequent generations in both family and non-family firms. The former continue to present higher levels of debt but in the second generation the

Table 2

Financing Structure by Generation.

\begin{tabular}{|c|c|c|c|c|c|c|c|c|}
\hline \multirow{3}{*}{ Debt } & \multicolumn{4}{|c|}{$1^{\text {st }}$ Generation $:<25$ Years } & \multicolumn{4}{|c|}{$2^{\text {nd }}$ Generation and Follows: $\geq 25$ Years } \\
\hline & \multicolumn{2}{|c|}{ Mean } & \multirow{2}{*}{ T Test } & \multirow{2}{*}{$\begin{array}{l}\text { Mann- } \\
\text { Whitney }\end{array}$} & \multicolumn{2}{|c|}{ Mean } & \multirow{2}{*}{ T Test } & \multirow{2}{*}{$\begin{array}{c}\text { Mann- } \\
\text { Whitney }\end{array}$} \\
\hline & Fam. & No Fam. & & & Fam. & No Fam. & & \\
\hline Total & 0,548 & 0,517 & $5.01 * * *$ & $5.59^{* * *}$ & 0,458 & 0,447 & $1.28^{*}$ & 1,42 \\
\hline Long-term & 0,092 & 0,097 & $-1,18$ & $-2.13 * *$ & 0,086 & 0,092 & $-1,16$ & $-3.09 * * *$ \\
\hline Short-term & 0,456 & 0,420 & $5.92 * * *$ & $6.06^{* * *}$ & 0,371 & 0,355 & $2.18^{* *}$ & $2.02 * *$ \\
\hline
\end{tabular}

Firms that did not comply with Article 35 of the Code of Commercial Societies (equity less than $50 \%$ of share capital), that did not indicate the number of employees in 2007, and without operational gains and sales, were excluded from the years of the period of analysis. Applying these criteria resulted in a sample of 13.527 family firms and 2.377 non-family firms for the year 2007. Besides the family ownership factor, this study aims to clarify how the size factor determines the financing decision. Therefore, two types of firm come closer in terms of total debt. This reduction in debt after the first generation was also found by MenéndezRequejo (2006) and Blanco-Mazagatos et al (2007). This development may be due to second generation firms being able to register a past of accumulated results and/or being at a more advanced stage of their life-cycle. Therefore, they need to make less investment with less need for external funding. 


\section{Table 3}

Sources of Finance by Generation.

Bank T Bank LTBank STOwners TOwners LTOwners STEqui. Su. TEqui. Su. LTEqui. Su. ST $1^{\text {st }}$ Generation

\begin{tabular}{|c|c|c|c|c|c|c|c|c|c|}
\hline Family & 0,109 & 0,037 & 0,071 & 0,080 & 0,034 & 0,046 & 0,050 & 0,017 & 0,033 \\
\hline No Family & 0,111 & 0,047 & 0,064 & 0,057 & 0,025 & 0,032 & 0,037 & 0,017 & 0,020 \\
\hline \multicolumn{10}{|l|}{ Tests } \\
\hline $\mathrm{T}$ test & 0,64 & $3.60 * * *$ & $-2.24 * *$ & $-5.79 * * *$ & $-3.31 * * *$ & $-4.37 * * *$ & $-4.94 * * *$ & 0,54 & $-6.83 * * *$ \\
\hline $\mathrm{M}-\mathrm{W}$ & $-1,11$ & $3.67 * * *$ & $-0,90$ & $-7.40 * * *$ & $-3.44 * * *$ & $-2.95 * * *$ & $-2.09 * *$ & $7.12 * * *$ & $-0,13$ \\
\hline \multicolumn{10}{|c|}{$2^{\text {nd }}$ Generation } \\
\hline Family & 0,108 & 0,041 & 0,068 & 0,068 & 0,032 & 0,036 & 0,029 & 0,011 & 0,018 \\
\hline No Family & 0,120 & 0,048 & 0,072 & 0,043 & 0,020 & 0,023 & 0,029 & 0,014 & 0,015 \\
\hline \multicolumn{10}{|l|}{ Tests } \\
\hline $\mathrm{T}$ test & $1.94 * *$ & $1.82 * *$ & 0,96 & $-5.05 * * *$ & $-3.12 * * *$ & $-3.68 * * *$ & $-0,05$ & $1.54 *$ & $-1.72 * *$ \\
\hline M-W & $2.44 * * *$ & $4.21 * * *$ & $2.80 * * *$ & $-3.77 * * *$ & $-4.22 * * *$ & $2.03 * *$ & $5.94 * * *$ & $6.20 * * *$ & $6.78 * * *$ \\
\hline
\end{tabular}

Table 3 shows very similar behaviour in terms of weight of total bank debt between the first generation of family and non-family firms. The differences between the two types of firm are in the level of maturity of this source of finance. Non-family firms present a greater proportion of medium and long-term bank debt, with the situation being inverted in the case of short-term debt. In the second generation, only non-family firms show an increase in this source of finance (mainly short-term). Family firms show a slight increase in long-term debt and a smaller proportion of short-term debt. In relation to financing by owners, there are more pronounced differences between family and non-family firms. The family firms resort more to this source. This aspect can justify the higher level of total debt in family firms as they resort more to financing by the owners. In both types of firms, a reduction in the use of owners' funding is found in the second generation. The first generation shows greater use of finance from equipment suppliers (including leasing) in family firms. This source can be relevant for meeting firms' funding needs (and in the specific case of family ones) as a function of the risk factor. This source allows both parties involved to face less exposure to financial risk than that felt in the case of other sources (for example, bank loans). For the financing body, the assets underlying the contract serve as its collateral (guarantee). In the case of family firms, this external source does not increase the firm's financial risk (to which they are averse) in the same way as traditional financing, and in principle, does not imply presentation of more assets (of the firm or personal) to obtain it. In the second generation, less use of this source is found, which may be justified by the previous arguments associated with less need for funding.

Table 4 does not show great differences between the generations of family firms regarding longer term zero debt. This aspect may have various explanations. These firms maintaining their aversion to debt since they hold on to their family character, or possible restrictions in accessing this source of finance. In non-family firms, differences are seen between generations. The second generation has a lower proportion of firms with zero medium and long-term debt (principally concerning bank debt), meaning they resort more frequently to debt.

The table confirms the situation previously referred to of family firms showing less frequent use of debt but in a greater proportion when they do so, compared to non-family firms. This difference is more pronounced in financing by owners and equipment suppliers. In the case of bank debt, non-family firms present a greater proportion, but only in the first generation. In the second generation, family firms present a greater proportion of bank debt. This result may indicate a greater tendency to use this source (less aversion) in family firms or fewer 
restrictions in long-term financing. Longer maturity allows better access to the financial market, and less creation of internal funding (compared to non-family firms) implies a greater need for external finance.

Table 5 presents the average values associated with the independent variables used in this study considering the generation factor.

Table 6 presents financing sources considering three size categories: micro, small and medium-sized/large. The results show family firms with higher levels of debt than non-family firms in all sizes. This holds true for all debt maturities, except for long-term debt in micro family firms. Micro firms (both types of firms) form the group with less debt. Small firms are seen to be the group with most debt (principally family firms). Medium-sized/large firms register a fall in debt compared to small ones. The lower debt in micro firms may be the result of restrictions in accessing the financial market (the lower proportion of long-term debt may indicate this aspect) or their leaders' decision to keep firms at a certain size. As for small firms, they may still be at an early stage of their life-cycle, and so in a situation of greater growth and investment, implying a greater need for finance not satisfied by internally generated funds. Medium-sized/large firms may be

Table 4

Firms with Zero Medium and Long-Term Debt by Generation.

\begin{tabular}{|c|c|c|c|c|c|c|c|c|}
\hline & \multicolumn{4}{|c|}{$\begin{array}{l}\text { Number of Firms with zero Long-term } \\
\text { Debt Ratio }\end{array}$} & \multicolumn{4}{|c|}{ Mean - Long-term Debt without zero } \\
\hline & Fam. & $\%$ & No Fam. & $\%$ & Fam. & No Fam. & T Test & $\begin{array}{l}\text { Mann- } \\
\text { Whitney }\end{array}$ \\
\hline \multicolumn{9}{|l|}{ 1st Generation } \\
\hline Debt - Overall & 5736 & $57,8 \%$ & 754 & $50,4 \%$ & 0,238 & 0,209 & $-3.79 * * *$ & $-5.28 * * *$ \\
\hline Bank Debt & 7835 & $79,0 \%$ & 1117 & $74,7 \%$ & 0,177 & 0,187 & 1,17 & $-0,42$ \\
\hline Owners' Funds & 7979 & $80,5 \%$ & 1255 & $83,9 \%$ & 0,174 & 0,153 & $-1.72 * *$ & $-2.44 * *$ \\
\hline Equip. Suppliers & 8285 & $83,5 \%$ & 1121 & $75,0 \%$ & 0,100 & 0,070 & $-4.70 * * *$ & $-7.36 * * *$ \\
\hline \multicolumn{9}{|l|}{ 2nd Generation } \\
\hline Debt - Overall & 1909 & $57,2 \%$ & 408 & $46,3 \%$ & 0,221 & 0,184 & $-3.95 * * *$ & $-4.42 * * *$ \\
\hline Bank Debt & 2562 & $76,7 \%$ & 609 & $69,0 \%$ & 0,175 & 0,154 & $-2.03 * * *$ & $-2.30 * *$ \\
\hline Owners' Funds & 2655 & $79,5 \%$ & 755 & $85,6 \%$ & 0,154 & 0,142 & $-0,72$ & $-1,43$ \\
\hline Equip. Suppliers & 2828 & $84,7 \%$ & 663 & $75,2 \%$ & 0,075 & 0,058 & $-2.24 * *$ & $-3.22 * * *$ \\
\hline
\end{tabular}

Table 5

Descriptive Statistics of the Independent Variables by Generation.

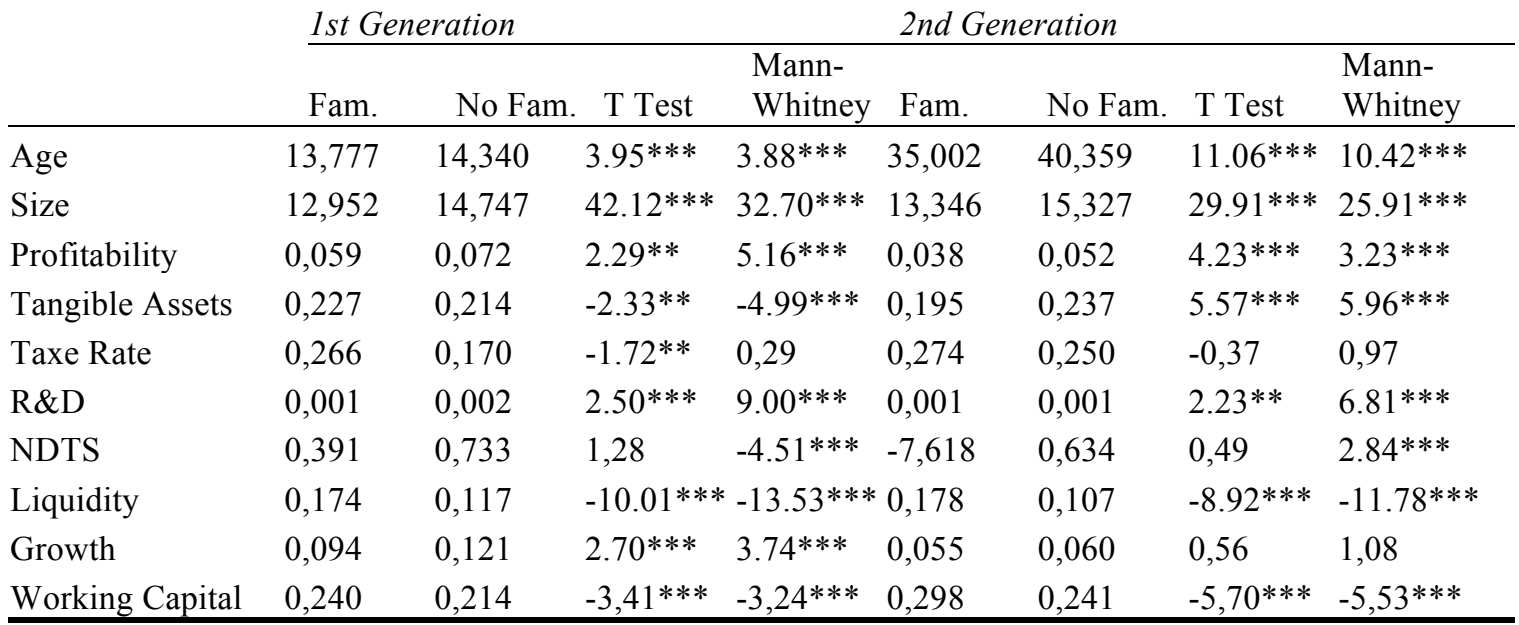


associated with a more mature stage of their life, or business, cycle, with less pronounced growth and investment, together with a longer past of accumulating funds and less need to resort to debt.

Table 7 allows assessment of the weight of the different sources. We see a positive relationship between size and use of bank debt and credit from equipment suppliers (more pronounced in the case of family firms). On the other hand, a negative relationship is found between size and owners' funding (here too with a greater range of variation in family firms). These results can be determined by the ownership and size factors. Increased size can promote access to the financial market. The literature gives various reasons for small firms' more restricted access to the financial market. Family firms are more averse to debt due to the increased financial risk, loss of control and greater exposure to third parties this represents. Larger size allows better access to the financial

Table 6

Sources of Finance by Size.

\begin{tabular}{|c|c|c|c|c|}
\hline \multirow[b]{3}{*}{ Micro } & \multicolumn{2}{|c|}{ Mean } & \multirow{2}{*}{ T Test } & \multirow{2}{*}{ Mann-Whitney } \\
\hline & Family & No Family & & \\
\hline & & & & \\
\hline Total Debt & 0,500 & 0,461 & $3.84 * * *$ & $3.77^{* * *}$ \\
\hline Long-term Debt & 0,081 & 0,085 & $-0,67$ & 0,11 \\
\hline $\begin{array}{l}\text { Short-term Debt } \\
\text { Small }\end{array}$ & 0,419 & 0,376 & $4.45^{* * *}$ & $4.43 * * *$ \\
\hline Total Debt & 0,570 & 0,508 & $8.29 * * *$ & $7.80 * * *$ \\
\hline Long-term Debt & 0,106 & 0,089 & $3.34 * * *$ & $4.43^{* * *}$ \\
\hline $\begin{array}{l}\text { Short-term Debt } \\
\text { Medium / Large }\end{array}$ & 0,465 & 0,419 & $6.20 * * *$ & $5.94 * * *$ \\
\hline Total Debt & 0,551 & 0,494 & $5.76^{* * *}$ & $5.76^{* * *}$ \\
\hline Long-term Debt & 0,113 & 0,108 & 0,92 & $3.28 * * *$ \\
\hline Short-term Debt & 0,437 & 0,386 & $5.67 * * *$ & $6.11^{* * *}$ \\
\hline
\end{tabular}

Table 7

Sources of Finance by Size.

\begin{tabular}{|c|c|c|c|c|c|c|c|c|c|}
\hline & Bank T & Bank LT & Bank ST & Owners T & $\begin{array}{c}\text { Owners } \\
\text { LT }\end{array}$ & $\begin{array}{c}\text { Owners } \\
\text { ST }\end{array}$ & $\begin{array}{c}\text { Equi. Su. } \\
\mathrm{T}\end{array}$ & $\begin{array}{c}\text { Equi. Su. } \\
\text { LT }\end{array}$ & $\begin{array}{c}\text { Equi. Su. } \\
\text { ST }\end{array}$ \\
\hline \multicolumn{10}{|l|}{ Micro } \\
\hline Family & 0,085 & 0,027 & 0,058 & 0,094 & 0,038 & 0,055 & 0,041 & 0,011 & 0,029 \\
\hline $\begin{array}{l}\text { No Family } \\
\text { Tests }\end{array}$ & 0,091 & 0,034 & 0,057 & 0,078 & 0,039 & 0,039 & 0,030 & 0,012 & 0,018 \\
\hline T t est & 0,87 & $1.76^{* *}$ & $-0,31$ & $-2.33 * * *$ & 0,13 & $-3.01 * * *$ & $-2.93 * * *$ & 0,04 & $-3.65 * * *$ \\
\hline $\mathrm{M}-\mathrm{W}$ & $-1,17$ & 0,52 & $-1,83$ & $-2.00 * *$ & 0,26 & $-1.65^{*}$ & $-4.02 * * *$ & 0,01 & $-3.65 * * *$ \\
\hline \multicolumn{10}{|l|}{$\underline{\text { Small }}$} \\
\hline Family & 0,142 & 0,054 & 0,088 & 0,053 & 0,027 & 0,026 & 0,051 & 0,020 & 0,030 \\
\hline $\begin{array}{l}\text { No Family } \\
\text { Tests }\end{array}$ & 0,120 & 0,051 & 0,070 & 0,039 & 0,015 & 0,025 & 0,035 & 0,017 & 0,019 \\
\hline $\mathrm{T}$ test & $-3.70 * * *$ & $-0,70$ & $-4,15 * * *$ & $-3.58 * * *$ & $-4.25 * * *$ & $-0,51$ & $-5.05 * * *$ & $-1.77 * *$ & $-5.29 * * *$ \\
\hline M-W & $-5.48 * * *$ & $-1.80 *$ & $-4.58 * * *$ & $-7.56 * * *$ & $-5.79 * * *$ & $-2.53 * *$ & $-6.22 * * *$ & 0,48 & $-3.78 * * *$ \\
\hline \multicolumn{10}{|c|}{ Medium / Larges } \\
\hline Family & 0,180 & 0,072 & 0,109 & 0,017 & 0,010 & 0,007 & 0,055 & 0,029 & 0,025 \\
\hline $\begin{array}{l}\text { No Family } \\
\text { Tests }\end{array}$ & 0,125 & 0,053 & 0,071 & 0,046 & 0,021 & 0,026 & 0,036 & 0,019 & 0,017 \\
\hline T test & $-7.01 * * *$ & $.35 * * *$ & $-6.40 * * *$ & $6.38 * * *$ & $3.23 * * *$ & $6.04 * * *$ & $-4.40 * * *$ & $3.02 * * *$ & $-4.17^{\circ}$ \\
\hline
\end{tabular}


market and, in the case of family firms, may reflect a more advanced stage in their life-cycle and their owners' greater tendency to resort to these sources. The results show a lower level of finance obtained through financial institutions being compensated for by resorting to owners' funding. And over the growth cycle, an exchange is found between the level of owners' funding and bank finance.

In larger firms there are more pronounced differences in the use of different sources of finance between family and non-family firms. The former tend to use more bank finance than the latter. As for owner funding, there is a slight increase in use among larger non-family firms. In the case of family firms, a significant fall is recorded between the two size categories.

Table 8 allows assessment of firms with zero long-term debt for each size category. Here, there is a negative relationship between size and the frequency of zero debt firms. Family firms tend to present a lower frequency of zero debt firms than non-family ones, except for micro firms which show similarity between the two types of firm. This group seems to show greater restrictions (or needs) regarding finance of longer maturity as a greater frequency of the zero ratio is found in the different sources analyzed. Indeed, the results indicate a positive relationship between size and the number of firms using long-term finance from financial institutions (bank credit and equipment suppliers). This relationship is more pronounced in the case of family firms. In relation to longterm finance from owners, there is a slightly greater frequency of use in small family firms, but around 4/5 of firms in the sample do not resort to this source. Analysis of the average values of the weight of debt, in firms without zero ratios in each source, shows an influence of zero values characterizing the financial structure of sample firms. For example, similarly to the results obtained by Ramalho and Silva (2009), small firms present a greater frequency of zero values, but show a greater proportion of longterm debt (when they use it), i.e., a negative relationship between size and the proportion of debt is found when, previously, there was a positive relationship in its use. This is common to both types of firm. However, when analyzing the proportion of each source, in the case of micro and medium-sized/large non-family firms, we observe a similarity between bank debt and owners' funding (although the former show a higher proportion of these sources). In the case of family firms, we see the importance of owners' funding in financing small firms. Increased size leads to a substitution (in proportion) of this source by bank credit.

Table 8

Firms with Zero Medium and Long-Term Debt by Size.

\begin{tabular}{|c|c|c|c|c|c|c|c|c|}
\hline \multirow[b]{2}{*}{ Micro } & \multicolumn{4}{|c|}{$\begin{array}{l}\text { Number of Firms with zero Long-term } \\
\text { Debt Ratio }\end{array}$} & \multicolumn{4}{|c|}{ Mean - Long-term Debt without zero } \\
\hline & Fam. & $\%$ & No Fam. & $\%$ & Fam. & No Fam. & $\mathrm{T}$ Test & $\begin{array}{l}\text { Mann- } \\
\text { Whitney }\end{array}$ \\
\hline Debt - Overall & 5488 & $65,9 \%$ & 394 & $65,2 \%$ & 0,259 & 0,264 & 0,35 & $-0,42$ \\
\hline Bank Debt & 7117 & $85,4 \%$ & 512 & $84,8 \%$ & 0,188 & 0,224 & $2.10 * *$ & 0,93 \\
\hline Owners' Funds & 6793 & $81,5 \%$ & 489 & $81,0 \%$ & 0,207 & 0,204 & $-0,17$ & $-0,74$ \\
\hline $\begin{array}{l}\text { Equip. Suppliers } \\
\text { Small }\end{array}$ & 7522 & $90,3 \%$ & 545 & $90,2 \%$ & 0,118 & 0,118 & 0,02 & $-0,41$ \\
\hline Debt - Overall & 1952 & $46,3 \%$ & 443 & $50,1 \%$ & 0,214 & 0,196 & $-1.99 * *$ & $-3.15 * * *$ \\
\hline Bank Debt & 2925 & $69,4 \%$ & 643 & $72,7 \%$ & 0,175 & 0,185 & 1,02 & 0,48 \\
\hline Owners' Funds & 3259 & $77,3 \%$ & 760 & $85,9 \%$ & 0,120 & 0,104 & $-1,23$ & $-1,49$ \\
\hline $\begin{array}{l}\text { Equip. Suppliers } \\
\text { Medium / Large }\end{array}$ & 3176 & $75,3 \%$ & 650 & $73,4 \%$ & 0,083 & 0,062 & $-2.97 * * *$ & $-4.05 * * *$ \\
\hline Debt - Overall & 205 & $29,0 \%$ & 325 & $36,6 \%$ & 0,174 & 0,177 & 0,36 & $-1,25$ \\
\hline Bank Debt & 355 & $50,1 \%$ & 571 & $64,3 \%$ & 0,144 & 0,149 & 0,57 & $-0,83$ \\
\hline Owners' Funds & 582 & $82,2 \%$ & 761 & $85,7 \%$ & 0,056 & 0,144 & $5.42 * * *$ & $4.38 * * *$ \\
\hline Equip. Suppliers & 415 & $58,6 \%$ & 589 & $66,3 \%$ & 0,070 & 0,057 & $-1.72 * *$ & $-4.07 * * *$ \\
\hline
\end{tabular}


In larger firms there are more pronounced differences in the use of different sources of finance between family and non-family firms. The former tend to use more bank finance than the latter. As for owner funding, there is a slight increase in use among larger non-family firms. In the case of family firms, a significant fall is recorded between the two size categories.

Table 8 allows assessment of firms with zero long-term debt for each size category. Here, there is a negative relationship between size and the frequency of zero debt firms. Family firms tend to present a lower frequency of zero debt firms than non-family ones, except for micro firms which show similarity between the two types of firm. This group seems to show greater restrictions (or needs) regarding finance of longer maturity as a greater frequency of the zero ratio is found in the different sources analyzed. Indeed, the results indicate a positive relationship between size and the number of firms using long-term finance from financial institutions (bank credit and equipment suppliers). This relationship is more pronounced in the case of family firms. In relation to longterm finance from owners, there is a slightly greater frequency of use in small family firms, but around $4 / 5$ of firms in the sample do not resort to this source. Analysis of the average values of the weight of debt, in firms without zero ratios in each source, shows an influence of zero values characterizing the financial structure of sample firms. For example, similarly to the results obtained by Ramalho and Silva (2009), small firms present a greater frequency of zero values, but show a greater proportion of longterm debt (when they use it), i.e., a negative relationship between size and the proportion of debt is found when, previously, there was a positive relationship in its use. This is common to both types of firm. However, when analyzing the proportion of each source, in the case of micro and medium-sized/large non-family firms, we observe a similarity between bank debt and owners' funding (although the former show a higher proportion of these sources). In the case of family firms, we see the importance of owners' funding in financing small firms. Increased size leads to a substitution (in proportion) of this source by bank credit.

Table 9 presents the descriptive statistics of the three categories and two types of firms.

\section{Estimation of Models}

This section presents the results obtained

Table 9

Descriptive Statistics of the Independent Variables by Size.

\begin{tabular}{|c|c|c|c|c|c|c|c|c|c|c|c|c|}
\hline & Micro & & & & Small & & & & Mediu & $n / L a r$ & & \\
\hline & $\begin{array}{l}\text { Mean } \\
\text { Fam. }\end{array}$ & $\begin{array}{l}\text { No } \\
\text { Fam. }\end{array}$ & $\mathrm{T}$ test & $\begin{array}{l}\text { Mann- } \\
\text { Whitney }\end{array}$ & $\begin{array}{l}\text { Mean } \\
\text { Fam. }\end{array}$ & $\begin{array}{l}\text { No } \\
\text { Fam. }\end{array}$ & $\mathrm{T}$ test & $\begin{array}{l}\text { Mann- } \\
\text { Whitney }\end{array}$ & $\begin{array}{l}\text { Mean } \\
\text { Fam. }\end{array}$ & $\begin{array}{l}\text { No } \\
\text { Fam. }\end{array}$ & $\mathrm{T}$ test & $\begin{array}{l}\text { Mann- } \\
\text { Whitney }\end{array}$ \\
\hline Age & 17,601 & 119,803 & $4.62 * * *$ & $* 2.80 * * *$ & 20,899 & 922,563 & $3.60 * * *$ & $1.91^{*}$ & 26,486 & 628,274 & $42.10 * *$ & $-0,15$ \\
\hline Size & 12,304 & 412,502 & $4.00 * * *$ & $* 4.30 * * *$ & 14,084 & 414,826 & $20.24 * * *$ & $* 19.04 * * *$ & 15,692 & 216,772 & $217.24 * * *$ & $* 16.70 * * *$ \\
\hline $\begin{array}{l}\text { Profitability } \\
\text { Tang. }\end{array}$ & 0,051 & 0,032 & $-2.18 * *$ & $-2.33 * *$ & 0,057 & 0,076 & $5.95^{* * *}$ & $3.35 * * *$ & 0,062 & 0,075 & $3.08 * * *$ & $2.08 * *$ \\
\hline Assets & 0,204 & 0,203 & $-0,07$ & $-2.76 * * *$ & 0,240 & 0,215 & $-3.42 * * *$ & $*-6.33 * * *$ & 0,279 & 0,242 & $-3.71 * * *$ & $*-5.55 * * *$ \\
\hline Taxe Rate & 0,248 & 0,226 & $-0,26$ & $-2.42 * *$ & 0,300 & 0,267 & $-0,61$ & $-1.87 *$ & 0,308 & 0,114 & $-1.30 *$ & $-1,45$ \\
\hline R\&D & 0,001 & 0,001 & 0,54 & 1,12 & 0,001 & 0,002 & $1.94 * *$ & 0,83 & 0,001 & 0,002 & 0,96 & 0,57 \\
\hline NDTS & $-2,858$ & 81,378 & $\begin{array}{l}0,33 \\
-\end{array}$ & $-4.23 * * *$ & 0,399 & 0,420 & 0,09 & $-6.98 * * *$ & 0,800 & 0,509 & $-0,77$ & $-3.40 * * *$ \\
\hline Liquidity & 0,212 & 0,186 & $2.59 * * *$ & $*-4.36 * * *$ & 0,118 & 0,103 & $-2.82 * * *$ & $*-5.45 * * *$ & 0,081 & 0,075 & $-1,12$ & $-3.65^{* * *}$ \\
\hline $\begin{array}{l}\text { Growth } \\
\text { Work. }\end{array}$ & 0,074 & 0,069 & $\begin{array}{l}-0,32 \\
-\end{array}$ & $-0,52$ & 0,100 & 0,100 & 0,01 & $-0,07$ & 0,105 & 0,115 & 0,59 & $-1,23$ \\
\hline Capital & 0,247 & 0,207 & $3.23 * * *$ & $*-3.37 * * *$ & 0,272 & 0,243 & $-3.15 * * *$ & $*-3.25 * * *$ & 0,249 & 0,217 & $-2.82 * * *$ & $*-2.93 * * *$ \\
\hline
\end{tabular}


with the econometric models and the respective analysis.

\subsection{Factors Determining the Use and} Proportion of Debt and the Generation Issue

This section aims to ascertain the impact of generations in the two-part econometric models, i.e., how the generation variable influences the determinants of use and proportion of debt. Therefore, reference will only be made to the differences introduced by this factor in the results of the econometric models estimated in the previous section. The age variable shows a reduction in the proportion of debt with increased age, as seen in the descriptive analysis. In the case of family firms, this variable is not significant for use of debt but is so in determining its proportion, presenting different signs between the two generations. The negative relationship in the first generation may mean that, at an initial stage of their life-cycle, firms' leaders seek a greater proportion of debt, but increased business maturity means a lower proportion of that debt (due to accumulation of internal funds). Indeed, the descriptive analysis showed a lower proportion of debt in the second generation than in the first. The first generation may have a greater aversion to debt but at an initial stage of business start-up they may feel a need to resort to it (since there are various sources which are not exclusively financial, for example, funding through the owners themselves). The positive relationship in the second generation means a greater tendency in these firms to use a greater proportion of debt as age increases. This result indicates a greater tendency towards debt in the third generation than in the second generation, contradicting the results obtained by Sonfield and Lussier (2004), Coleman and Carsky (1999) and Cole and Wolken (1995). These authors observed a more moderate level of debt in the third generation than in the second.

In the case of the size variable, there is a significant and positive relationship with the

Table 10

Two-Part Fractional Regression Model - Generation and Long-term Debt.

\begin{tabular}{|c|c|c|c|c|c|c|c|c|}
\hline & \multicolumn{4}{|c|}{$1^{\text {st }}$ Generation } & \multicolumn{4}{|c|}{$2^{\text {nd }}$ Generation } \\
\hline & \multicolumn{2}{|l|}{ Family } & \multicolumn{2}{|c|}{ No Family } & \multicolumn{2}{|l|}{ Family } & \multicolumn{2}{|c|}{ No Family } \\
\hline & Part 1 & Part II & Part 1 & Part II & Part 1 & Part II & Part 1 & Part II \\
\hline \multirow[t]{2}{*}{ Age } & 0,00 & 0,00 & 0,00 & $-0,01$ & 0,00 & 0,00 & 0,00 & 0,00 \\
\hline & $-0,82$ & $-1.93 *$ & $-0,27$ & $-2.91 * * *$ & 0,30 & $1.92 *$ & $-0,16$ & $-2.22 * *$ \\
\hline \multirow[t]{2}{*}{ Size } & 0,34 & $-0,08$ & 0,20 & $-0,02$ & 0,27 & $-0,07$ & 0,20 & $-0,01$ \\
\hline & $18.61 * * *$ & $-12.05 * * *$ & $6.36 * * *$ & $-2.02 * *$ & $9.79 * * *$ & $-6.73 * * *$ & $4.48 * * *$ & $-0,93$ \\
\hline \multirow[t]{2}{*}{ Profitability } & $-1,13$ & $-0,89$ & $-0,76$ & $-0,85$ & $-1,19$ & $-0,89$ & $-2,16$ & $-1,08$ \\
\hline & $-4.62 * * *$ & $-7.29 * * *$ & $-1,51$ & $-3.42 * * *$ & $-2.31 * *$ & $-3.50 * * *$ & $-2.38 * *$ & $-3.39 * * *$ \\
\hline \multirow[t]{2}{*}{ Tangible } & 1,38 & 0,64 & 2,34 & 0,60 & 1,26 & 0,52 & 3,30 & 0,22 \\
\hline & $10.85 * * *$ & $11.42 * * *$ & $7.51 * * *$ & $4.95 * * *$ & $4.94 * * *$ & $5.20 * * *$ & $6.93 * * *$ & 1,32 \\
\hline \multirow[t]{2}{*}{ Tax rate } & 0,02 & 0,02 & 0,23 & $-0,03$ & $-0,02$ & 0,00 & $-0,03$ & $-0,03$ \\
\hline & 0,70 & 1,41 & $1.76^{*}$ & $-1,37$ & $-0,73$ & $-0,20$ & $-0,23$ & $-1,04$ \\
\hline \multirow[t]{2}{*}{ R\&D } & 2,35 & 0,48 & $-1,08$ & $-0,38$ & $-1,61$ & $-1,66$ & $-2,75$ & $-5,71$ \\
\hline & 1,36 & 1,34 & $-0,22$ & $-0,17$ & $-0,27$ & $-0,74$ & $-0,32$ & $-2.75 * * *$ \\
\hline \multirow[t]{2}{*}{ NDTS } & 0,00 & 0,00 & 0,03 & 0,00 & 0,00 & 0,00 & 0,01 & 0,00 \\
\hline & 0,55 & 0,23 & 1,59 & 0,42 & 0,99 & $2.55 * *$ & 0,55 & $-0,82$ \\
\hline \multirow[t]{2}{*}{ Liquidity } & $-1,30$ & 0,02 & $-1,13$ & $-0,32$ & $-2,44$ & $-0,13$ & $-1,30$ & $-0,19$ \\
\hline & $-8.66 * * *$ & 0,27 & $-2.64 * * *$ & $-1.76^{*}$ & $-8.26 * * *$ & $-0,92$ & $-2.15 * *$ & $-0,77$ \\
\hline \multirow[t]{2}{*}{ Growth } & 0,21 & 0,10 & 0,09 & 0,07 & 0,49 & 0,14 & 0,83 & 0,25 \\
\hline & $3.11 * * *$ & $3.45 * * *$ & 0,92 & 0,88 & $2.40 * *$ & $1.82 *$ & $1.95^{*}$ & $1.97 * *$ \\
\hline \multirow[t]{2}{*}{ Work capital } & 0,48 & 0,42 & 0,23 & 0,07 & 0,07 & 0,29 & 0,57 & $-0,10$ \\
\hline & $4.59 * * *$ & $7.41 * * *$ & 0,91 & 0,62 & 0,35 & $3.42 * * *$ & 1,53 & $-0,60$ \\
\hline \multirow[t]{2}{*}{ Constant } & $-5,16$ & 0,69 & $-4,07$ & 0,35 & $-4,19$ & 0,13 & $-3,37$ & $-0,20$ \\
\hline & $-18.51 * * *$ & $6.04 * * *$ & $-6.89 * * *$ & 1,45 & $-7.73 * * *$ & 0,74 & $-4.20 * * *$ & $-0,72$ \\
\hline
\end{tabular}


issue of long-term debt through external bodies in all types of firms. In determining the proportion of debt, a negative and statistically significant relationship is found. These results confirm that large firms use more long-term debt but small firms do so in a greater proportion when they manage to gain access. Small firms face more restrictions in accessing the financial market and so present a lower frequency of using debt, but when they gain access they use a greater proportion than large firms. However, this behaviour can also be explained by the fact of small firms facing higher transaction costs when using external sources of finance, and therefore they resort to them less frequently but for larger amounts to compensate for that lower frequency (Ramalho and Silva, 2009). The results obtained with the profitability variable clearly confirm the aspect of the theory of pecking order where selffinancing emerges as the main source. This variable presents a negative, statistically significant relationship with the use of debt and determination of its proportion. Increased profitability means more internal funds and less need to turn to debt. This aspect is common to family and non-family firms. Tangible assets influence significantly and positively the decision to use debt and its proportion in both family and non-family firms, due to their collateral value. Firms with greater amounts of this type of asset have greater access to the financial market and a greater proportion of debt. This relationship also proves the suitability of the maturity of applications to the funds they finance.

In the model of the first generation of nonfamily firms, the result of the tax rate confirms the hypothesis of the relationship between tax rate and debt, presenting a positive and significant relationship. This factor is not relevant for family firms in determining the use and proportion of debt. The hypothesis associated with R\&D investment is confirmed in the second part of the model of second generation non-family firms (the only model showing this variable as significant). This aspect may result from this type of investment being possibly more relevant in non-family firms of some maturity. Nevertheless, given the risk of this type of asset, these firms tend to have a lower proportion of debt.

The NDTS variable is only significant in the second part of the second generation family firm model but with an opposite sign to the one expected, reflecting the aspects previously mentioned. The growth rate variable is clearly significant in determining the use and proportion of debt in family firms. Growth implies a greater need to use external finance more frequently and in greater proportions. In the case of non-family firms, it is only relevant for determining a greater proportion of debt. The liquidity variable presents a negative and significant relationship with the use of debt confirming that greater liquidity means less need to use debt. This variable is only significant in determining the proportion of debt in non-family firms but maintains the sign of the relationship. In the case of family firms, the non-significant relationship can be explained by their tendency to maintain high liquidity, even revealing higher levels of debt. The working capital needs variable is only significant for family firms. A greater volume of these needs means a greater need of external funding. In this relationship, it is relevant that the sign reflects the assumptions pointed out in the financial literature on how working capital needs should be financed.

In analyzing the results obtained in the following econometric models, it was decided to refer to the relevant differences or aspects compared to the results obtained in the first models. The results of the econometric models relating to the influence of generation on bank debt confirm less use of this source of finance in second generation firms. Increased age leads to less use of bank debt. In the case of family firms, this result confirms the observations of the descriptive analysis where an increase of second generation firms with zero debt was found. The second non-family generation recorded a reduced number of firms with zero debt between the first and second generation. Increased size leads to greater use of this source (both types of firms) and in a greater proportion (in family firms). This result confirms the hypothesis about the relationship between size 
and access to the financial market. Profitability is not relevant in determining the proportion of bank debt in second generation family firms. This variable was not considered relevant in determining the use of total debt in the first generation of non-family firms. These results may be the consequence of the latter being the group of firms with the best performance (showing profitability of 7,9\%) and the former being the group with the worst performance $(4,1 \%)$.

The positive relationship between $R \& D$ investment and the use and proportion of bank debt, found previously, is confirmed for both generations of family firms. Given the possible difficulty of financing this type of investment through financial institutions, this result may be relevant in explaining the level of innovation registered in family firms. The NDTS variable presents differences in the sign of the relationship in the second part of the models of family firms of the first (negative) and second (positive) generation. Therefore, only in the first case is the hypothesis confirmed. In the second, the relationship between this variable and tangible assets is reflected. Confirmation of the hypothesis associated with the tax rate in the models of bank debt occurs in first generation firms (family and non-family). This relationship may occur due to these being greater users of this source than second generation firms.

\subsection{Factors Determining the Use and} Proportion of Debt and the Size Issue

This section introduces the matter of size in determining the use and proportion of debt, classifying the sample of family and non-family firms in the three size categories previously referred to. The age variable is significant and with a negative sign in the first part of the models of family firms, showing that increased age leads to less use of debt in the three size categories. This only occurs in small non-family firms. As for determining the proportion of debt, significance (negative sign) is only found in the models of small non-family firms. These firms tend to use a lower proportion of debt. In the descriptive analysis of the sample period we saw this aspect confirmed by this econometric model, finding a reduction of debt in the three groups over the five-year period analyzed.

In the case of the size variable, a significant and positive relationship is found with the issue of debt in all sizes of family firms, and a nonsignificant one in non-family firms. In the second part of the model, this was only significant in small family firms and with the opposite sign from the one obtained in the first part of the model. These results mean that increased size leads to more use of long-term debt but in smaller proportions. This behaviour can be explained by the fact of small firms being more averse to debt due to the financial risk or being exposed to greater restrictions in access to finance. Besides, transaction costs are more significant in small firms. Therefore, when they gain access to finance, they seek a greater proportion for current and future needs. Increased size allows greater access and lower costs, and so these firms can obtain funds more frequently without needing to get large amounts each time. This variable is not significant for non-family firms, except for the second part of the model of medium-sized/large non-family firms where they present a positive relationship.

The profitability and tangible assets variables maintain the relationships referred to throughout this study, confirming the respective hypotheses. In the latter case, there is a clear relationship between tangible assets and longterm finance. The average tax rate is not significant in any of the models and $R \& D$ investment is only significant in the second part of the models of non-family micro and mediumsized/large firms, confirming the hypothesis. The liquidity variable is confirmed as an important determinant of family firms' financing decision, mainly in determining the use of debt. The negative and statistically significant sign in the first part of all family firm models indicates that firms with greater liquidity need less external funding. However, this variable is irrelevant in determining the proportion. Only in the case of medium-sized/large non-family firms is it seen to be significant. Indeed, Graph 7 illustrates that this size category presents a greater volume of liquidity than its family 
Table 11

Two-Part Fractional Regression Model - Generation and Bank Debt.

\begin{tabular}{|c|c|c|c|c|c|c|c|c|}
\hline & \multicolumn{4}{|c|}{$1^{\text {st }}$ Generation } & \multicolumn{4}{|c|}{$2^{\text {nd }}$ Generation } \\
\hline & \multicolumn{2}{|l|}{ Family } & \multicolumn{2}{|c|}{ No Family } & \multicolumn{2}{|l|}{ Family } & \multicolumn{2}{|c|}{ No Family } \\
\hline & Part 1 & Part II & Part 1 & Part II & Part 1 & Part II & Part 1 & Part II \\
\hline \multirow[t]{2}{*}{ Age } & 0,00 & 0,00 & 0,02 & 0,00 & $-0,01$ & 0,00 & $-0,01$ & 0,00 \\
\hline & 0,26 & $-0,75$ & 1,51 & $-0,30$ & $-3.33 * * *$ & $-0,49$ & $-1.69^{*}$ & $-0,95$ \\
\hline \multirow[t]{2}{*}{ Size } & 0,50 & 0,04 & 0,10 & 0,01 & 0,41 & 0,06 & 0,10 & 0,01 \\
\hline & $24.84 * * *$ & $7.50 * * *$ & $3.27 * * *$ & 1,26 & $13.44 * * *$ & $6.86 * * *$ & $2.09 * *$ & 0,90 \\
\hline \multirow[t]{2}{*}{ Profitability } & $-1,75$ & $-0,58$ & $-2,00$ & $-0,59$ & $-1,40$ & $-0,06$ & $-3,97$ & $-0,80$ \\
\hline & $-6.80 * * *$ & $-6.53 * * *$ & $-3.70 * * *$ & $-2.59 * * *$ & $-2.64 * * *$ & $-0,33$ & $-3.95 * * *$ & $-2.79 * * *$ \\
\hline \multirow[t]{2}{*}{ Tangible } & 0,68 & 0,40 & 1,44 & 0,41 & 0,89 & 0,30 & 1,40 & 0,04 \\
\hline & $5.17 * * *$ & $10.21 * * *$ & $4.60 * * *$ & $4.07 * * *$ & $3.31 * * *$ & $3.83 * * *$ & $2.97 * * *$ & 0,30 \\
\hline \multirow[t]{2}{*}{ Tax rate } & 0,06 & 0,01 & 0,20 & $-0,01$ & 0,05 & 0,00 & 0,29 & 0,02 \\
\hline & $1.86^{*}$ & 0,86 & $1.73 *$ & $-0,57$ & 1,02 & 1,06 & 1,55 & 0,81 \\
\hline \multirow[t]{2}{*}{$\mathrm{R} \& \mathrm{D}$} & 12,25 & 0,96 & $-1,11$ & 0,22 & 53,16 & 3,14 & 12,80 & $-0,17$ \\
\hline & $2.21 * *$ & $3.09 * * *$ & $-0,23$ & 0,13 & $2.27 * *$ & $4.27 * * *$ & 0,91 & $-0,12$ \\
\hline \multirow[t]{2}{*}{ NDTS } & 0,00 & 0,00 & $-0,01$ & 0,01 & 0,00 & 0,00 & 0,01 & 0,00 \\
\hline & 0,82 & $-3.75 * * *$ & $-0,91$ & $1.68^{*}$ & 1,43 & $2.17 * *$ & 0,89 & $-1,45$ \\
\hline \multirow[t]{2}{*}{ Liquidity } & $-2,42$ & 0,08 & $-3,92$ & $-0,09$ & $-4,04$ & $-0,13$ & $-6,49$ & $-0,70$ \\
\hline & $-15.75 * * *$ & 1,61 & $-7.95 * * *$ & $-0,47$ & $-12.84 * * *$ & $-1,26$ & $-7.74 * * *$ & $-2.53 * *$ \\
\hline \multirow[t]{2}{*}{ Growth } & 0,23 & 0,16 & 0,12 & 0,10 & 0,80 & 0,20 & 0,84 & 0,23 \\
\hline & $3.14 * * *$ & $6.66 * * *$ & 1,25 & 1,32 & $3.53 * * *$ & $2.99 * * *$ & $1.89^{*}$ & 1,53 \\
\hline \multirow[t]{2}{*}{ Work capital } & 0,43 & 0,54 & 0,64 & 0,48 & 0,12 & 0,44 & 0,70 & 0,33 \\
\hline & $3.99 * * *$ & $16.33 * * *$ & $2.46^{* *}$ & $5.53 * * *$ & 0,60 & $7.24 * * *$ & $1.77 *$ & $2.94 * * *$ \\
\hline \multirow[t]{2}{*}{ Constant } & $-5,78$ & $-1,15$ & $-1,63$ & $-0,76$ & $-4,38$ & $-1,22$ & $-1,09$ & $-0,87$ \\
\hline & $-19.64 * * *$ & $-13.32 * * *$ & $-2.80 * * *$ & $-3.95 * * *$ & $-7.48 * * *$ & $-7.54 * * *$ & $-1,32$ & $-3.59 * * *$ \\
\hline
\end{tabular}

counterpart. In the other two sizes, family firms present clearly greater liquidity than their nonfamily counterparts.

The growth rate is significant for all models of family firms (except for the first part of the model of small ones). In non-family firms, that significance only appears in the second part of the model of small ones and the first part of the medium-sized/large ones. So these results seem to show growth as a factor determining the decision to use debt and its proportion. And this variable has a more prominent role in family firms. These may have more need of external funding than their non-family counterparts due to less creation of internal finance. The relationship between working capital needs and long-term finance is only significant in family firms. And among these, micro firms show a positive relationship with the use and proportion of long-term debt. In the next sizes, only the relationship with the proportion is significant. One possible explanation is that micro firms hold less equity and need to resort to outside capital more than the other size categories.

Table 11 presents estimation of the models by the different size categories for total bank debt. The next paragraphs will only mention the contribution of these models to clarifying the financial process compared to the previous models. The results associated with the age variable (significant and with a negative sign) in the first part of the models of small family firms indicate less use of bank debt with increased age. This behaviour may be due to small family firms' aversion to financial debt. In these, the arguments about family firms are more likely to apply since at this size there may be more concentration of management and decisions in the family or a single family member. Nevertheless, the arguments about the existence of internally generated funds and the restrictions faced by these firms may also be valid. The descriptive analysis showed large family firms to be greater users (in terms of the frequency of 
the number of firms using it) of this source than their non-family counterparts.

In this source of finance, a positive (and statistically significant) relationship is observed between size and use in all size categories of family firms and in small non-family firms. That is to say, increased size increases the use of bank debt, as was demonstrated in the descriptive analysis. The results associated with the age and size variable may show two types of family firm behaviour within each of the smaller size categories. A set of firms that increase the use of bank debt as their size increases (increased size meaning greater growth and greater needs, and simultaneously greater access to the financial market). And another set of firms, more averse to financial debt, that use their life-cycle and funds generated so far by the business, and use less bank debt as their age increases. For example, one reason will be having reached a certain size and chosen to limit growth to internally generated funds. However, the second part of the small, family firm models also reveals a positive and significant sign for this relationship. The previous models showed a negative relationship with the proportion of debt. Therefore, these results mean for these firms an exchange of sources of finance in family firms as size increases, for example, increasingly less use of owners' funding and greater use of bank debt, as observed in the descriptive analysis.

\section{Table 12}

Two-part Fractional Regression Model - Size and Long-term Debt.

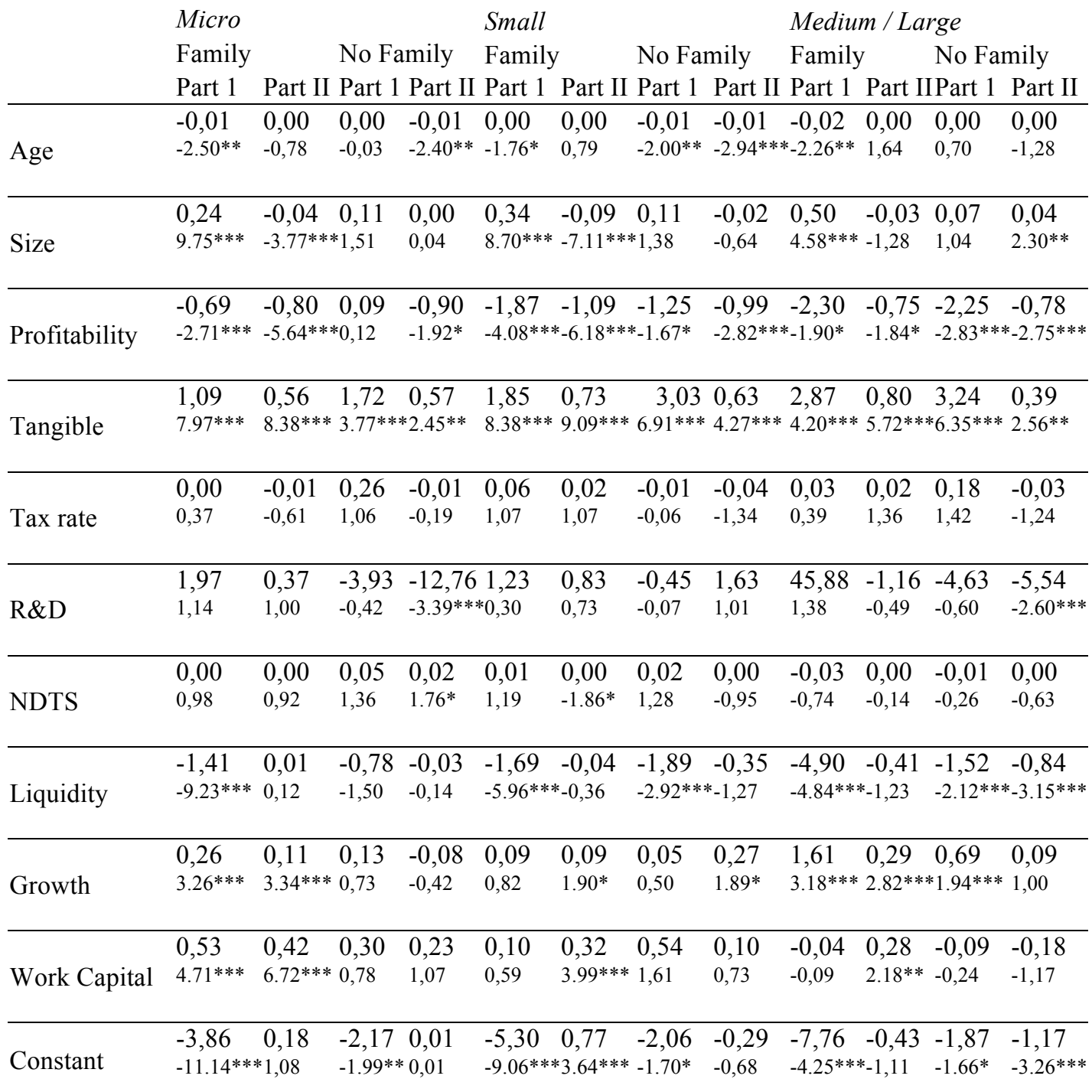


The average tax rate is of some relevance in determining the financing decision of large family firms, confirming the hypothesis. The results confirm the importance of bank finance for funding R\&D activities in small family firms when the financial literature refers to a negative relationship between this type of investment and debt.

Growth has a relevant role in determining the use and proportion of bank debt in small family firms. This significance only occurs in the models of large non-family firms. Bank finance is therefore observed as a source of reference for the growth of micro and small family firms.

\section{Discussion of the Hypotheses and Conclusions}

This section goes on to make a critical analysis of the results and their relationship with the hypotheses tested. The first hypothesis (H1) consisted of testing for differences or similarities in the financial structure decision, and specifically in capital structure, between family and non-family firms. The results showed greater debt in the former (statistically significant). The maturity of debt is a relevant factor in the financing process of both types of firm. Family firms present higher levels of short-term debt and lower levels of long-term debt. Accordingly, the results of this study confirm the arguments of the approach in the financial literature that defends greater debt in family firms. In addition, financial structures seem to show family firms' greater restrictions in accessing long-term debt. However, the sample reveals the smaller size of family firms and this factor may determine the results obtained.

\section{Table 13}

Two-part Fractional Regression Model- Size and Bank Debt.

\begin{tabular}{|c|c|c|c|c|c|c|c|c|c|c|c|c|}
\hline & \multirow{2}{*}{\multicolumn{2}{|c|}{$\begin{array}{l}\text { Micro } \\
\text { Family }\end{array}$}} & \multicolumn{6}{|c|}{ Small } & \multicolumn{4}{|c|}{ Medium / Large } \\
\hline & & & \multicolumn{2}{|c|}{ No Family } & \multicolumn{2}{|l|}{ Family } & \multicolumn{2}{|c|}{ No Family } & \multicolumn{2}{|c|}{ Family } & \multicolumn{2}{|c|}{ No Family } \\
\hline & Part 1 & Part II & Part 1 & Part II & IPart 1 & Part II & Part 1 & Part II & Part 1 & Part II & Part 1 & Part II \\
\hline \multirow[t]{2}{*}{ Age } & $-0,01$ & 0,00 & $-0,01$ & 0,00 & $-0,01$ & 0,00 & $-0,01$ & 0,00 & $-0,01$ & 0,00 & 0,00 & 0,00 \\
\hline & $-5.41 * * *$ & $-0,60$ & $-0,81$ & $-0,74$ & $-4.12 * * *$ & $-0,60$ & $-1,12$ & $-0,58$ & $-1,41$ & 0,77 & $-0,03$ & $-0,54$ \\
\hline \multirow[t]{2}{*}{ Size } & 0,50 & 0,05 & 0,15 & 0,04 & 0,41 & 0,06 & 0,16 & 0,02 & 0,25 & $-0,01$ & $-0,02$ & 0,02 \\
\hline & $19.68 * * *$ & $5.64 * * *$ & $1.95^{*}$ & 1,51 & $9.01 * * *$ & $6.04 * * *$ & $1.85^{*}$ & 0,97 & $2.02 * *$ & $-0,64$ & $-0,27$ & 1,01 \\
\hline \multirow[t]{2}{*}{ Profitability } & $-1,16$ & $-0,30$ & $-1,43$ & 0,01 & $-2,84$ & $-0,71$ & $-3,10$ & $-0,79$ & $-3,97$ & $-0,97$ & $-3,22$ & $-1,06$ \\
\hline & $-4.49 * * *$ & $-2.87 * * *$ & $-1.70 *$ & 0,03 & $-5.56^{* * *}$ & $-5.51 * * *$ & $-3.80^{* * *}$ & $*-2.94 * * *$ & $*-2.79 * * *$ & $*-4.50 * * *$ & $*-3.81 * *$ & $*-3.54 * * *$ \\
\hline \multirow[t]{2}{*}{ Tangible } & 0,52 & 0,34 & 0,78 & 0,26 & 1,20 & 0,48 & 2,01 & 0,36 & 1,71 & 0,38 & 1,83 & 0,39 \\
\hline & $3.80 * * *$ & $6.97 * * * *$ & $1.75^{*}$ & 1,53 & $4.75 * * *$ & $8.47 * * *$ & $4.35 * * *$ & $2.94 * * *$ & $2.23 * *$ & $3.08 * * *$ & $3.78 * * *$ & $2.83^{* * *}$ \\
\hline \multirow[t]{2}{*}{ Tax rate } & 0,04 & 0,00 & 0,33 & 0,08 & 0,08 & 0,02 & 0,19 & $-0,01$ & 0,21 & 0,02 & 0,18 & 0,00 \\
\hline & 1,57 & 0,22 & 1,17 & 1,58 & 1,06 & $1.78^{*}$ & 1,23 & $-0,66$ & $1.73^{*}$ & 1,46 & 1,40 & 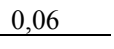 \\
\hline \multirow[t]{2}{*}{$\mathrm{R} \& \mathrm{D}$} & 12,01 & 0,99 & $-7,67$ & 2,01 & 30,85 & 1,43 & $-2,17$ & $-0,56$ & 14,02 & $-0,44$ & 26,60 & 0,11 \\
\hline & $1.94 *$ & $3.24 * * *$ & $-0,83$ & 0,32 & $1.91^{*}$ & 1,23 & $-0,31$ & $-0,26$ & 0,43 & $-0,16$ & 1,63 & 0,09 \\
\hline \multirow[t]{2}{*}{ NDTS } & 0,00 & 0,00 & 0,03 & 0,01 & 0,00 & 0,00 & 0,00 & 0,00 & $-0,06$ & $-0,01$ & $-0,01$ & 0,00 \\
\hline & 0,95 & $-0,73$ & 0,96 & $4.44 * * *$ & $* 1,12$ & 0,23 & $-0,42$ & $-0,80$ & $-1,39$ & $-0,28$ & $-0,32$ & $-0,18$ \\
\hline \multirow[t]{2}{*}{ Liquidity } & $-2,42$ & 0,04 & $-4,02$ & $-0,11$ & $-3,74$ & 0,00 & $-5,25$ & $-0,21$ & $-8,43$ & $-0,81$ & $-5,24$ & $-0,56$ \\
\hline & \multicolumn{2}{|c|}{$-15.86^{* * *} 0,71$} & \multicolumn{2}{|c|}{$-6.46 * * *-0,41$} & \multicolumn{2}{|c|}{$-11.96 * * * 0,03$} & \multicolumn{2}{|c|}{$-6.90 * * *-0,77$} & \multicolumn{4}{|c|}{$-7.30 * * *-3.00 * * *-5.87 * * *-1.95 *$} \\
\hline \multirow[t]{2}{*}{ Growth } & 0,17 & 0,17 & 0,09 & 0,23 & 0,57 & 0,17 & 0,05 & 0,01 & 0,71 & 0,17 & 1,40 & 0,21 \\
\hline & $2.10 * *$ & $5.76 * * *$ & 0,51 & 1,13 & $3.62 * * *$ & $4.44 * * *$ & 0,46 & 0,10 & 1,32 & $2.10^{* *}$ & $3.28 * * *$ & $1.65^{*}$ \\
\hline \multirow{4}{*}{$\begin{array}{l}\text { Work capit } \\
\text { Constant }\end{array}$} & 10,30 & 0,42 & $-0,09$ & 0,21 & 0,52 & 0,68 & 0,92 & 0,44 & 0,79 & 0,53 & 1,10 & 0,64 \\
\hline & $2.69 * * *$ & $11.12 * * *$ & $-0,24$ & 1,43 & $2.66 * * *$ & $14.02 * * *$ & $* 2.54 * *$ & $4.22 * * *$ & 1,30 & $5.29 * * *$ & $2.73 * * *$ & $5.53 * * *$ \\
\hline & $-5,51$ & $-1,27$ & $-0,95$ & $-0,88$ & $-4,59$ & $-1,48$ & $-2,14$ & $-0,84$ & 0,32 & $-0,29$ & 0,39 & $-0,69$ \\
\hline & \multicolumn{2}{|l|}{$-15.73 * * *$} & $*-0,87$ & $-1.94 *$ & $-6.92 * * *$ & $-9.14 * * *$ & $-1,63$ & $-2.33 * *$ & 0,13 & $-0,87$ & 0,34 & $-2.05 * *$ \\
\hline
\end{tabular}


Regarding the maturity of debt, in the firm sample a significant number of zeros is found in financing sources of long maturity (principally in family firms for total and bank debt). This result may indicate these firms' possible restrictions in accessing debt with longer maturity.

In the formation of the two types of firms' capital structure, differences were observed between the levels of financing sources used. Bank credit is the main source. Non-family firms presented slightly higher levels of this source (more evident in long maturity since family firms showed higher levels of short-term debt). The two other relevant sources were credit from owners and equipment suppliers. Family firms presented higher levels of both these sources, revealing their importance for this type of firm. The results indicate family firms' preference for this source due to greater aversion to financial debt or possible restrictions in accessing bank finance.

The financial literature points to less aversion to debt in second generation family firms $(\mathrm{H} 2)$. Therefore, those firms would be expected to present more debt in their financial structures. Nevertheless, the results show the opposite. Second generation firms of both types reveal lower levels of debt. However, family firms continue to show greater debt (despite the statistical relevance not being as obvious as in the case of the first generation resulting from the approximation between the two types of firms, as mentioned above). This lower debt in second generation firms resulted from a greater accumulation of results and increased share capital. Among the three most relevant financing sources, less use of credit from owners and equipment suppliers is found in second generation firms and constant or slightly increased levels of bank debt. However, an increase of zero values of bank debt is observed in second generation family firms when the same generation of non-family firms register a decrease.

The size factor $(\mathrm{H} 3)$ is seen to be an important determinant of firms' financial structure. Micro firms present lower levels of debt (of both maturities) than small and medium-sized/large ones. Small firms present the highest levels of debt, essentially short-term. Medium-sized/large firms are the group with the highest levels of long-term debt. In this maturity, some similarity is observed between family and non-family micro firms and between family and non-family medium-sized/large firms. In terms of evolution, micro firms present an increase in equity and a reduction of total debt which is more pronounced than in the other two sizes. There is a negative relationship between size and the scale of this evolution.

Larger family firms show a lower frequency of long-term zero debt than their non-family counterparts and a negative relationship between size and zero debt, but in the case of micro firms this is inverted. Zero values are relevant in both size categories (principally in small firms). These results hold true in the specific situation of total bank debt. Around $50 \%$ of micro firms do not resort to this source. Small and medium-sized/large firms present a weight of $28 \%$ and $18 \%$ of firms in this situation. The models revealed some differences between the factors determining the use of longterm debt compared to those determining its proportion, and between family and non-family firms (H4).

The greater debt in family firms than in nonfamily ones corroborates the financial line of thought which defends this behaviour. But this only occurs with total and short-term debt. With long-term debt, the situation is inverted, which may reveal these firms face some restrictions in accessing debt of a longer maturity. This fact can also be explained by banking institutions' preference for granting more short-term debt to reduce problems of information asymmetry, because it means the debt must be renegotiated more frequently. Family firms show greater use of debt from owners and equipment suppliers, particularly in the first generation. The results do not allow confirmation of whether this behaviour is due to greater restrictions in accessing debt or the option of family firm leaders given their aversion to debt. The second generation shows lower levels of debt than the first. Nevertheless, between the generations in both types of firms (family and non-family), the same differences mentioned previously are 
observed. The high failure rate of family firms may justify this lower debt in the second generation (when the literature indicates they are less averse to debt) since only the most conservative firms remain in the market, or it may be associated with a more mature stage of their life-cycle and less need to invest.

\section{Bibliography}

Akyüz, K. C., Akyüz, I., Serin, H. and Cindik, H. (2006). The Financing Preferences and Capital Structure of Micro, Small and Medium Sized Firm Owners in Forest Products Industry in Turkey. Forest Policy and Economics, 8, 301-311.

Andersen, R. C. and Reeb, D. M., (2003). Founding-Family Ownership and Firm Performance. Evidence from the S\&P 500. The Journal of Finance, 58(3), 1301-1328.

Ang, J. S. (1992). On The Theory of Finance for Privately Held Firms. The Journal of Small Business Finance, 1(3), 185-203.

Ang, J. S. (1991). Small Business Uniqueness and the Theory of Financial Management. Journal of Small Business Finance, 1(1), 1-13.

Antoniou, A., Guney, Y. and Paudyal, K. (2006). The Determinants of Debt Maturity Structure: Evidence from France, Germany and the UK. European Financial Management, 12(2), 161-194.

Barton, Sidney L., and Gordon, Paul J. (1987). Corporate Strategy: Useful Perspective for the Study of Capital Structure? Academy of Management Review, 12(1), 67-75.

Barton, S. L. and Matthews (1989), Small Firm Financing: Implications from a Strategic Management Perspective. Journal of small Business Management, 27(1), 1-7.

Blanco-Mazagatos, V., Quevedo-Puente, E. and Castrillo, L. A. (2007). The Trade-Off Between Financial Resources and Agency Costs in the Family Business: An Exploratory Study. Family Business Review, 20(3), 199-213.

Bork, D., Jaffe, D. T., Lane, S. H., Dashew, L. and Heisler, Q. G. (1996). Working with Family Businesses: A Guide for Professionals, San Francisco: Jossey-Bass Inc., Publishers.

Brailsford, T. Oliver, B. and Pua, S. (2002). On Relation between Ownership Structure and Capital Structure. Accounting and Finance, 42, 1-26.
Cassar, G. (2004). The Financing of Business Start-ups. Journal of Business Venturing, 19, 261283.

Cassar, G. and Holmes, S. (2003). Capital Structure and Financing of SMEs: Australian Evidence, Accounting \& Finance, 43(2), 123-147.

Chaganti, R., DeCarolis, D. and Deeds, D (1995), Predictors of Capital Structure in Small Ventures, Entrepreneurship Theory Practice, 20(2), 7-18.

Chittenden, F.; Hall, G. and Hutchinson, P. (1996). Small Firm Growth, Access to Capital Markets and Financial Structure: Review of Issues and an Empirical Investigation. Small Business Economics, 8, 59-67.

Cole, Rebel A. and Wolken, John D. (1995). Financial Services Used by Small Businesses: Evidence from the 1993 National Survey of Small Business Finances. Federal Reserve Bulletin, 81, 629-667.

Coleman, Susan; Carsky, Mary, (1999). Sources of Capital for Small Family-Owned Businesses: Evidence from the National Survey of Small Business Finances. Family Business Review, 12(1), 73-86.

DeAngelo, H. and Masulis, R. W. (1980). Optimal Capital Structure Under Corporate and Personal Taxation. Journal of Financial Economics, 8, 3-29.

Dyer, W. Gibb (2003). The Family: The Missing Variable in Organizational Research, Entrepreneurship Theory and Practice, 27(4), 401416.

Ebben, J. and Johnson, A. (2006). Bootstrapping in Small Firms: An Empirical Analysis of Change Over Time. Journal of Business Venturing, 21(6), 851-865.

Faulkender, M. and Petersen, M. A. (2006). Does the Source of Capital Affect Capital Structure? Review of Financial Studies, 19(1), 45-79.

Friend, I. and Lang, L. (1988). An Empirical Test of the Impact of Managerial Self-interest on Corporate Capital Structure. Journal of Finance, 43(2), 271-281.

Gallo, M. A., Tàpies, J. and Cappuyns, K. (2004), Comparison of Family and Nonfamily Business: Financial Logic and Personal Preferences. Family Business Review, 17(4), 303-318.

Gersick, K. F., Hampton, M. M., Lansberg, I. and Davis, J. A. (1996). Generation to Generation: Life 
Cycles of the Family Business, Boston: Harvard University Press.

Harris, Milton and Raviv, Artur (1991). The Theory of Capital Structure, The Journal of Finance, 46(1), 297-355.

Harris, Milton, Artur Raviv, (1988). Corporate Control Contests and Capital Structure, Journal of Financial Economics, 20, 55-86.

Harvey, M. and Evans, R. (1995). Forgotten Sources of Capital for the Family-Owned Business, Family Business Review, 8(3), 159-176.

Haugen, R. and Senbet, L. (1988). Bankruptcy and Agency Costs: Their Significance to the Theory of Optimal Capital Structure. Journal of Financial and Quantitative Analysis, 23, 27-38.

Hoy, F. (2003). Legitimizing Family Business Scholarship in Organizational Research and Education. Entrepreneurship Theory and Practice, 27(4), 417-422.

Jensen, Michael (1986). Agency Cost of Free Cash Flow, Corporate Finance, and Takeovers. American Economic Review, 76(2), 323-329.

Jensen, M. C. and Meckling, W.H. (1976). Theory of the Firm: Managerial Behaviour, Agency Costs, and Ownership Structure. Journal of Financial Economics, 3(4), 305-360.

Kraus, A., and R. Litzenberger (1973). A StatePreference Model of Optimal Leverage, The Journal of Finance, 28, 911-920.

Kurshev, A. and Strebulaev, I. A. (2007). Firm Size and Capital Structure, (Mimeo).

La Porta, R.; Lopez-de-Silanes, F. and Shleifer, A. (1999). Corporate Ownership Around the World, The Journal of Finance, 54, 471-518.

Lank, A. G. (1995). key Challenges Facing Family Enterprise, Lausanne, Switzerland: IMD Publication.

Leland, H. E. and Pyle D. H. (1977). Informational Asymmetries, Financial Structure, and Financial Intermediation. The Journal of Finance, 32(2), 371-387.

López-Gracia, J. and Aybar-Arias, C. (2000), An Empirical Approach to the Financial Behaviour of Small and Medium Sized Companies. Small Business Economics, 14, 55-63.

López-Gracia, J. and Sánchez-Andújar, S. (2007). Financial Structure of the Family Business:
Evidence from a Group of Small Spanish Firms. Family Business Review, 20(4), 269-287.

McConaughy, D. L.; Matthews, C. H. and Fialko, A. S. (2001). Founding Family Controlled Firms: Performance, Risk, and Value. Journal of Small Business Management, 39(1), 31-49.

Menéndez-Requejo, S. (2006). Ownership Structure and Firm Performance: Evidence from Spanish Family Firms, Chapter 31 in Poutziouris et al (2006).

Miller, Merton H., (1977). Debt and Taxes. The Journal of Finance, 32(2), 261-275.

Modigliani, F. and Miller, M. H. (1958). The Cost of Capital, Corporation Finance and The Theory of Investment. American Economic Review, 48(3), 261-297.

Modigliani, F. and Miller, M. (1963). Corporate Income Taxes and the Cost of Capital: A Correction. American Economic Review, 437-447.

Myers, S. C. (1977). Determinants of Corporate Borrowing. Journal of Financial Economics, 5, 147175.

Myers, S. C. and Majluf, N. S. (1984). Corporate Financing and Investment Decisions When Firms Have Information That Investors Do Not Have. Journal of Financial Economics, 13(2), 187-221.

Neubauer, F., Lank, A. (1998), The Family Business: Its Governance for Sustainability, London: MacMillan Press Lda.

Poutziouris, P. Z. (2006). The Structure and Performance of the UK Family Business PLC economy, Chapter 30 in Poutziouris et al (2006).

Poutziouris, Panikkos Z. (2001), The Views of Family Companies on Venture Capital: Empirical Evidence from the UK Small to Medium-Size Enterprising Economy. Family Business Review, 14(3), 277- 291.

Rajan, Raghuram and Zingales, Luigi (1995). What Do We Know About Capital Structure? Some Evidence from International Data. The Journal of Finance, 50, 1421-1460.

Ramalho, J. and Silva, J. (2009). A Two-part Fractional Regression Model for the Financial Leverage Decisions of Micro, Small, Medium and Large Firms, Quantitative Finance, 9(5), 621-636.

Romano, C. A. Tanewski, G. A. and Smyrnios, K. X. (2000), Capital Structure Decision Making: A Model for Family Business. Journal of Business Venturing, 16, 285-310. 
Ross, S. A. (1977). The Determination of Financial Structure: The Incentive Signalling Approach. Bell Journal of Economics, 8(1), 23-40.

Schulze, W. S.; Lubatkin, M. H.; Dino, R. N. (2003), Toward a Theory of Agency and Altruism in Family Firms. Journal of Business Venturing, 18, 473-490.

Schulze, W. S.; Lubatkin, M. H.; Dino, R. N. and Buchholtz, A. K. (2001). Agency Relationships in Family Firms: Theory and Evidence. Organization Science, 12(2), 99-116.

Sirmon, D. G. and Hitt, M. A. (2003). Managing Resources: Linking Unique Resources, Management, and Wealth Creation in Family Firms. Entrepreneurship Theory and Practice, 27(4), 339358.

Smith, Max (2008). Differences Between Family and Non-Family SMEs: A Comparative Study of Australia and Belgium, Journal of Management \& Organization, 14(1), 40-58.

Sonfield, M. and Lussier, R. (2004). First, Second and Third Generation Family Firms: A Comparison. Family Business Review, 17(3), 189202.

Strebulaev, I. A. and Yang, B. (2007). The Mystery of Zero-Leverage Firms, (Mimeo).

Titman, Sheridan and Wessels, Robert, (1988), The Determinants of Capital Structure Choice, The Journal of Finance, 43(1), 1-21.

Ward, J. (1987). Keeping the Family Business Healthy, Jossey Bass: San Francisco.

Westhead, P. and Howorth, C. (2007). Types of Private Family Firms: An Exploratory Conceptual and Empirical Analysis. Entrepreneurship \& Regional Development, 19, 405-431. 